\title{
PENYELESAIAN SENGKETA EKONOMI SYARIAH MENJADI KEWENANGAN PENGADILAN AGAMA PASCA PUTUSAN MAHKAMAH KONSTITUSI NOMOR 93/PUU-X/2012
}

\author{
Redi Hadiyanto \\ Fakultas Syariah Universitas Islam Bandung \\ redihadiyanto@unisba.ac.id
}

\begin{abstract}
ABSTRAK
Penelitian ini dilatar belakangi oleh fenomena tentang Penyelesaian Sengketa Ekonomi Syariah yang pada awalnya bisa diselesaikan di pengadilan agama juga dipengadilan umum. Tidak ada kepastian hukum. Sedangkan kepastian hukum setiap warga negara itu dijamin dan diatur dalam undang-undang dasar 1945 pasal 28D ayat (1), didalam pasal tersebut menyatakan bahwa negara menjamin kepastian hukum setiap warga negaranya. Tujuan dari penelitian ini adalah memahami tentang penghapusan penjelasan pasal 55 ayat 2 undang-undang nomor 21 tahun, untuk menjamin kembali kepastian hukum tersebut, maka undang-undang nomor 21 tahun 2008 tersebut harus diuji materil ke Mahkamah Konstitusi untuk menjamin kepastian hukum setiap warga negara. Metode yang digunakan dalam penelitian ini adalah analisis isi (content analysis) yaitu menganalisis Putusan Mahkamah Konstitusi Nomor 93/PUU-X/2012. Selain itu, penelitian ini juga menggunakan pendekatan sosiologis dan normatif-yuridis. Hasil penelitian menunjukan Mahkamah Konstitusi, megabulkan permohonan uji materil yang diajukan para pemohon, dengan hasil putusan Mahakamah Konstitusi nomor 93/PUU$\mathrm{X} / 2012$, bahwa penjelasan pasal 55 ayat 2 undang-undang nomor 21 tahun 2008 dihapuskan karena tidak menjamin kepastian hukum setiap warga negara. Sehingga setelah putusan mahkamah konstitusi ini disahkan maka perkara Penyelesaian Sengketa Ekonomi Syariah menjadi kewenangan absolut pengadilan agama, tidak bisa diproses dan diputus diluar pengadilan agama.
\end{abstract}

Kata Kunci : Penyelesaian Sengketa Ekonomi Syariah, Pengadilan Agama .

\begin{abstract}
This research is motivated by the phenomenon of the Sharia Economic Dispute Settlement which could initially be resolved in a religious court also in the general court. There is no legal certainty. While the legal certainty of each citizen is guaranteed and regulated in the 1945 constitution article 28D paragraph (1), in that article states that the state guarantees the legal certainty of each citizen. The purpose of this study is to understand about the elimination of the explanation of article 55 paragraph 2 of law number 21 years, to reassure the certainty of the law, then law number 21 of 2008 must be tested materially to the Constitutional Court to guarantee the legal certainty of every citizen.
\end{abstract}


The method used in this research is content analysis, namely analyzing the Constitutional Court Decision Number 93 / PUU-X / 2012. In addition, this research also uses sociological and normative-juridical approach. The results showed that the Constitutional Court granted the material test petition submitted by the petitioners, with the result of Constitutional Court decision number 93 / PUU-X / 2012, that the explanation of article 55 paragraph 2 of law number 21 of 2008 was abolished because it did not guarantee the legal certainty of every citizen country. So that after the ruling of the constitutional court is ratified, the Sharia Economic Dispute Settlement case becomes the absolute authority of the religious court, it cannot be processed and decided outside the religious court.

\section{Keywords: Sharia Economic Dispute Settlement, Religious Courts}

\section{A. PENDAHULUAN}

Dibandingkan dengan negara lain di dunia, regulasi hukum ekonomi syariah di Indonesia termasuk agak terlambat, hal ini bertolak belakang dengan aktivitasnya yang berkembang dengan pesat dan signifikan. ${ }^{1}$ didalam penjelasan Undang-Undang Nomor 3 tahun 2006 Pasal 49 huruf (i) dimana pasal dan isinya tidak dirubah dalam UndangUndang Nomor 50 Tahun 2009 Tentang Perubahan Kedua Undang-Undang Nomor 7 Tahun 1989 Tentang Peradilan Agama, dalam Undang-Undang tersebut disebutkan bahwa Peradilan Agama bertugas dan berwenang mengadili dan menyelesaikan perkara di tingkat pertama antara orang-orang yang beragama Islam dalam bidang ekonomi syariah, ${ }^{2}$ dalam penjelasan pasal 49 UU No. 3 Tahun 2006 tentang Peradilan Agama disebutkan bahwa yang dimaksud dengan ekonomi syariah adalah perbuatan atau kegiatan usaha yang dilaksanakan berdasarkan prinsip syariah, meliputi : bank syariah, lembaga keuangan mikro syariah, asuransi syariah, reasuransi syariah, reksadana syariah, obligasi syariah dan surat berharga berjangka menengah syariah, sekuritas syariah, pembiayaan syariah, pegadaian syariah, dana pensiun lembaga keuangan

\footnotetext{
${ }^{1}$ Demikian pula pada awal pendirian Bank Muamalat Indonesia 1 November 1991, keberadaan Bank Syariah ini belum mendapatkan perhatian yang optimal dalam tatanan industri perbankan nasional. Landasan hukum operasi bank yang menggunakan system syariah ini hanya dikategorikan sebagai "bank dengan sistem bagi hasil"tidak terdapat perincian landasan hukum syariah serta jenis-jenis usaha yang dibolehkan. system bagi hasil dalam undang-undang nomor 7 tahun tahun 1992 tentang perbankan hanya diuraikan sepintas lalu merupakan "sisipan"belaka. Lihat : Muhammad Syafei Antonio, Islamic Bank : Bank Syariah dari Teori ke Praktek. (Jakarta:,Gema Insani Press, 2001), hlm. 26.

${ }^{2}$ Amran Suadi, Penyelesaian Sengketa Ekonomi Syariah.( Surabaya: Kencana, 2017), hlm. 49.
} 
syariah, dan bisnis syariah. ${ }^{3}$

Dasar dari sebuah ekonomi adalah merupakan kegiatan yang tidak terlepas dari harta dan benda. Dikatakan kegiatan ekonomi apabila ada sebuah transaksi ekonomi antara satu pihak dengan pihak yang lain, yang terkadang transaksi tersebut menimbulkan sebuah sengketa. Sengketa dalam Kamus Besar Bahasa Indonesia adalah segala sesuatu yang menyebabkan perbedaan pendapat, pertikaian atau perbantahan. ${ }^{4}$ Dalam Kamus Inggris kata sengketa, perselisihan, pertentangan sama dengan conflict atau dispute. ${ }^{5}$ Oleh karena itu kata lain dari sengketa adalah konflik, secara bahasa kedua kata tersebut mengandung arti suatu peristiwa yang menggambarkan tentang adanya perbedaan atau benturan kepentingan antara dua pihak atau lebih. Konflik adalah keadaan dimana apabila dua pihak atau lebih dihadapkan pada perbedaan kepentingan berkembang menjadi sebuah sengketa (wanprestasi) apabila pihak yang merasa dirugikan telah menyatakan rasa tidak puas atau keprihatinannya, baik secara langsung kepada pihak yang dianggap sebagai penyebab kerugian atau kepada pihak lain. ${ }^{6}$

\section{B. METODE PENELITIAN}

Metode yang digunakan dalam penelitian ini adalah analisis isi (content analysis) yaitu menganalisis Putusan Mahkamah Konstitusi Nomor 93/PUU-X/2012. Selain itu, penelitian ini juga menggunakan pendekatan sosiologis dan normatif-yuridis, yaitu pendekatan disiplin ilmu dan teori hukum yang berfungsi untuk penyelesaian sengketa ekonomi syariah, dengan cara mengumpulkan, mengevaluasi, memverifikasikan, serta mensintesiskan bukti-bukti untuk mendukung fakta memperoleh kesimpulan yang kuat. ${ }^{7}$

\footnotetext{
${ }^{3}$ Andri Soemitro, Hukum Ekonomi Syariah dan Fiqh Muamalah di Lembaga Keuangan dan Bisnis Kontemporer.( Jakarta: Prenada Media, 2019), hlm. 3.

${ }^{4}$ Departemen Pendidikan dan Kebudayaam, Kamus Besar Bahasa Indonesia (Jakarta: Balai Pustaka, 1990), hlm 643

5 John.M. Echlos dan Hasan Shadily, Kamus Inggris Indonesia dan Indonesia Inggris, (Jakarta: Gramedia, 1996), hlm 138

${ }^{6}$ Koentjaraningrat, Kebudayaan Metaliteit dan Pembangunan, (Jakarta: Gramedia, 1982), hlm 103.

${ }^{7}$ Lexy J . Melong, Metodologi Penelitian Kualitatif (Bandung : Remaja Rosdakarya. 1999), hlm. 138 dan Husain Usman dan Purnomo Setiady Akbar, Metodologi Penelitian Sosial (Jakarta: Bumi Aksara. 2003), cet. ke-3, hlm. 4.
} 


\section{PEMBAHASAN}

\section{Dalil-Dalil Hukum Para Ahli dalam Putusan Mahkamah Konstitusi Nomor 93/PUU-X/2012}

Saksi ahli dari pihak pemohon dalam perkara terkait Putusan Mahkamah Konstitusi Nomor 93/PUU-X/2012 yaitu Dr. Ija Suntana dan Prof. Dr. H. Dedi Ismatullah, SH., MH., dan telah didengar keterangannya di bawah sumpah dalam persidangan tanggal 20 Desember 2012.

Keterangan ahli pertama Dr. Ija Suntana memberikan pendapat bahwa: ${ }^{8}$

Pertama, Bahwa pasal a quo dalam istilah hukum Islam akan menimbulkan yang disebut dengan ta'arudh al-adillah, pertentangan dua aturan ketika ayat (2) dan ayat (3) Undang-Undang a quo masih tetap ada. Menurut ahli, Pasal 2 dan 3 Undang-Undang $a$ quo bertentangan dengan Pasal 1 ayat (3) sehingga menimbulkan adanya ketidakpastian hukum dan bertentangan dengan Pasal 28D ayat (1) UUD1945.

Kedua, Adanya pilihan forum untuk penyelesaian perkara, dan juga diberikannya kebebasan untuk memilih dan tidak ditunjuk langsung oleh Undang-Undang, hal tersebut akan menimbulkan chaos sebelum atau dalam praktik akad. Sebab mungkin saja ketika seseorang mau menandatangani akad di Bank Syariah, sementara pihak bank menginginkan penyelesaian sengketa di pengadilan negeri, sedangkan nasabah menginginkan diselesaikan di pengadilan agama, hal tersebut akan menimbulkan masalah dalam akad tersebut.

Ketiga, Menurut ahli ketika diberikan kesempatan choice of forum adalah membahayakan apabila ada ungkapan bahwa orang yang masuk ke Bank Syariah bukan orang muslim saja, tetapi ada non muslim. Dalam teori hukum ketika orang non muslim masuk kepada peradilan atau perbankan syariah, dia telah melakukan choice of law (telah memilih hukum). Ketika dia telah memilih hukum, maka secara langsung dia siap dan ikut diatur dengan aturan dan asas yang ada di lembaga yang dia masuki, yaitu hal-hal yang terkait dengan syariah dan ketika bank syariah menerapkan aturan-aturan syariah, maka ketika non muslim masuk ke dalam bank syariah telah menyiapkan diri dan siap juga menerima terhadap aturan yang diterapkan oleh bank syariah, sehingga dari urusan

\footnotetext{
${ }^{8}$ Putusan MK RI Nomor Nomor 93/PUU-X/2012, hlm. 27-28.
} 
asas, aturan, dan sampai penyelesaian sengketanya harus disesuaikan dengan syariah. Oleh sebab itu, dikatakan bahwa non muslim yang telah masuk ke dalam bank syariah telah melakukan choice of law karena ada bank konvensional yang dapat dipilih, karena di bank syariah telah dijelaskan secara nyata bahwa aturan dan asas yang telah dilaksanakan mulai akad sampai penyelesaian sengketa sesuai dengan aturan syariah.

Keterangan ahli kedua dari pemohon yaitu Prof. DR. H. Dedi Ismatullah, SH. Memberikan pendapat yaitu: ${ }^{9}$

Pertama, bahwa Pasal 1 ayat (3) UUD 1945, negara Indonesia adalah negara hukum yang di dalamnya ada dua pengertian yaitu supreme of law dan equality before the law. Penafsiran terhadap supreme of law yaitu salah satunya adalah kepastian hukum, rechtstaat adalah kepastian hukum, maka dengan diberikannya pilihan hukum bagi orang yang masuk di peradilan, akan menimbulkan confuse atau kebingungan hukum. Oleh karena itulah, maka ahli melihat Pasal 2 ayat (2) dan ayat (3) tidak rasional, sebab bertentangan dengan ayat (1). Salah satunya adalah dilaksanakan peradilan di peradilan agama tetapi diberikan pilihan di peradilan yang lain. Hal tersebut juga akan bertentangan dengan Undang-Undang Nomor 50 Tahun 2009 tentang Kompetensi Peradilan Agama. Kompetensi peradilan agama adalah merupakan kepastian hukum bagi orang yang ingin berperkara di dalam masalah bank ekonomi Islam.

Kedua, Menurut ahli melaksanakan ekonomi syariah di peradilan agama adalah merupakan bentuk daripada implementasi Pasal 29 ayat (2) UUD 1945, maka negara mempunyai kewajiban melindungi hak-hak hukum bagi setiap warga negaranya. Selain itu, Pasal 28 ayat (1) UUD 1945, sudah jelas tentang kepastian hukum, yaitu setiap orang berhak atas pengakuan jaminan perlindungan dan kepastian hukum yang adil serta perlakuan yang sama di hadapan hukum. Menurut ahli, bahwa equality before the law adalah samanya kedudukan antara pengadilan agama dan pengadilan negeri, tetapi oleh karena pengadilan agama telah dijustifikasi oleh Undang-Undang tersendiri, sehingga ini adalah merupakan kompetensi absolut bagi peradilan agama.

Saksi ahli yang diundang Mahkamah Konstitusi perkara Nomor 93/PUU-X/2012 yaitu Muhammad Syafi'i Antonio yang telah memberikan keterangan dalam persidangan

\footnotetext{
${ }^{9}$ Ibid. hlm. 28.
} 
tanggal 29 Januari 2013. ${ }^{10}$

Pertama, Bahwa terkait dengan dispute settlement option, sebelum Tahun 2006, dispute settlement option yang terjadi antara perbankan syariah dengan nasabah memang hampir seluruhnya hanya satu, yaitu Badan Arbitrase Syariah Nasional, disebut dengan Basyarnas. Biasanya dalam perjanjian antara bank dengan nasabahnya dicantumkanlah arbitration clause. Bank sebagai pihak pertama, nasabah sebagai pihak kedua, keduanya sepakat untuk menunjuk Badan Arbitrase Syariah Nasional sebagai pemutus konflik atau dispute di antara kedua belah pihak. Biasanya apapun putusan dari Basyarnas ini bersifat final and binding, bersifat mengikat dan tidak boleh ada upaya hukum lanjutan Setelah 2006, kemudian ada Undang-Undang Perbankan Syariah memberikan opsi kepada keuangan dan perbankan syariah untuk memilih apakah akan ke Basyarnas saja atau akan ke pengadilan agama? Di sana diberikan dua opsi, ahli melihat dalam kasus ini memang ada satu masalah utama dan yang kedua ada masalah turunannya. Masalah utamanya seperti yang tadi disampaikan oleh Pemohon, selaku kontraktor Benua Engineering Construction ada permasalah dari Bohir yang memberikan pekerjaan kepada nasabah, yang kemudian terjadi pembayaran yang tidak sesuai dari harapan, sehingga mungkin hal ini dilihat oleh bank sebagai suatu nasabah yang tidak memenuhi cicilannya.

Kedua, Bahwa catatan ahli yang mendasar, adalah memang ada suatu penafsiran dari pihak lembaga keuangan terhadap Pasal 55 di Undang-Undang Perbankan Syariah Nomor 21 Tahun 2008 di Pasal 55 ayat (1): “Penyelesaian sengketa perbankan syariah dilakukan oleh pengadilan dalam lingkungan peradilan agama". Ayat (2) "Dalam hal para pihak telah memperjanjikan penyelesaian sengketa selain sebagaimana dimaksud pada ayat (1), penyelesaian sengketa dilakukan sesuai dengan isi akad”. Bahwa dalam penjelasan Pasal 55 sebagai berikut, ayat (1) cukup jelas dan ayat (2) yang dimaksud dengan penyelesaian sengketa dilakukan sesuai dengan isi akad adalah upaya sebagai berikut : a. Musyawarah, b. Mediasi perbankan, c. Melalui Badan Arbitrase Syariah Nasional (Basyarnas), d. Atau lembaga arbitrase lain dan/atau melalui pengadilan dalam lingkungan peradilan umum.

Ketiga, Bahwa menurut ahli, boleh jadi lembaga keuangan dimaksud mengambil

\footnotetext{
${ }^{10}$ Ibid. hlm. 33-35.
} 
opsi yang (d) ini, sehingga nasabah di awal menganggap ini ada Basyarnas, sementara lembaga keuangan yang bersangkutan mengambil opsi (d) ini. Jadi, di sinilah mungkin yang dibawa ke Mahkamah Konstitusi ini, apakah ini tidak menjadikan satu conflict of dispute settlement karena mungkin ada 2 atau bahkan 3 pemutus konflik di sini, satu Basyarnas, kedua peradilan agama, yang ketiga peradilan umum.

Keempat, Bahwa dalam pengamatan ahli, ini bukan kasus yang pertama, tetapi ini sudah belasan kali, jikalau tidak puluhan kali terjadi. Selain itu menurut ahli, untuk menghilangkan dispute ada dua langkah, pertama, ketika terjadi perjanjian antara nasabah dengan lembaga keuangan syariah harus dijelaskan betul bahwa apa opsi dispute settlement dan ketika opsi dispute settlement sudah ditetapkan, misalnya, Badan Arbitrase Syariah Nasional, maka pihak pertama dan pihak kedua sepakat menjadikan Basyarnas sebagai one and the only dispute settlement body dan apa pun putusannya bersifat final and binding dan tidak boleh ada upaya hukum lainnya. Apabila ada upaya hukum lainnya setelah itu, maka batal demi hukum. Kedua, seandainya yang akan dipilih adalah pengadilan agama, maka keduanya juga menyepakatinya sesuai dengan aturan yang berlaku dan supaya tidak terjadi dispute, menurut ahli, jikalau masih dibuka peluang untuk pergi ke pengadilan umum, akan membuat konflik antara peradilan agama dan peradilan umum. Sehingga, menurut ahli akan lebih baik mencabut poin (d) karena menurut ahli menghilangkan pintu ketiga untuk pergi ke peradilan umum, tetapi hanya Basyarnas saja dan/atau hanya peradilan di lingkungan Peradilan Agama saja sehingga dengan demikian sudah menjadi clear dan tidak terulang masalah ini di kemudian hari.

\section{Dasar Hukum Para Hakim Mahkamah Konstitusi dalam Putusan Mahkamah Konstitusi Nomor Perkara Nomor 93/PUU-X/2012}

Pertimbangan hukum hakim dalam sebuah putusan (ratio decidendi) merupakan bahan hukum primer yang menjadi salah satu objek kajian ilmuwan hukum. Dalam pertimbangan hukum dimaksud intinya berisi tentang analisis majelis hakim terhadap fundamentum petendi sebagaimana yang didalilkan oleh para pihak. Guna melengkapi pertimbangan hukum dimaksud dalam tulisan ini, selain mengkaji Putusan atas perkara $a$ quo Penulis mengemukan pula beberapa hal penting dalam risalah persidangan pra 
putusan atas uji materi Pasal 55 ayat (2) dan (3) Undang-Undang Nomor 21 Tahun 2008 tentang Perbankan Syariah di keluarkan.

Pertama, pada sidang pertama tertanggal 5 Oktober 2012, Dadang Ahmad yang memberikan kuasa kepada Rudi Hermawan dan Sophan Irawan selaku advokat menyampaikan poin-poin penting sebagaimana tertuang dalam Permohonan yang diajukan kepada Kepaniteraan Mahkamah Konstitusi. Bahwa demi adanya kepastian hukum yang dijamin oleh Pasal 28D Undang-Undang Dasar Negara Republik Indonesia Tahun 1945, memohon kepada Majelis Hakim Mahkamah Konstitusi berkenan mengabulkan permohonan Pemohon sebagaimana tertuang dalam surat permohonan tertanggal 12 Agustus 2012 yang intinya menyatakan bahwa materi muatan ayat (2) Pasal 5 Undang-Undang Nomor 21 Tahun 2008 tentang Perbankan Syariah bertentangan dengan Pasal 28D dimaksud. ${ }^{11}$ Oleh karenanya materi muatan ayat (2) Pasal 5 UndangUndang Nomor 21 Tahun 2008 tentang Perbankan Syariah tidak mempunyai kekuatan hukum mengikat.

Kedua, dalam panggilan sidang kedua tertanggal 19 Oktober 2012 pihak pemohon tidak hadir, sehingga persidangan dinyatakan selesai. Dalam konteks ini pihak yang ada hanya Pemohon, sementara termohon adalah suatu undang-undang. Adapun Pemerintah dan/atau DPR hanya merupakan pihak yang dimintai keterangan. Oleh karena itu dalam hal Pemohon tidak hadir tidak berarti perkara gugur sebagaimana dalam persidangan di pengadilan biasa.

Ketiga, dalam kesempatan sidang ketiga tertanggal 28 November 2012 berbeda dengan sidang pertama dan kedua karena dihadiri oleh 9 (sembilan) Hakim Mahkamah Konstitusi, yakni: Moh. Mahfud MD selaku Ketua, dengan anggota Ahmad Fadlil Sumadi, Achmad Sodiki, Anwar Usman, M. Akil Mochtar, Muhammad Alim, Maria Farida Indrati, Harjono, dan Hamdan Zoelva. Pada kesempatan sidang ketiga ini pula hadir utusan dari Pemerintah dan DPR untuk didengarkan keterangannya.

Keterangan pertama diberikan oleh Adang Daradjatun yang merupakan wakil dari Komisi III DPR RI. Keterangan DPR RI terhadap dalil Pemohon sebagaimana

${ }^{11}$ Pasal 28D ayat (1) UUD 1945 "Setiap orang berhak atas pengakuan, jaminan, perlindungan, dan kepastian hukum yang adil serta perlakuan yang sama dihadapan hukum." 
diuraikan dalam permohonan a quo: ${ }^{12}$ Dengan keterangan tersebut, DPR RI meminta Majelis Hakim Mahkamah Konstitusi untuk memeriksa, memutus, dan mengadili perkara a quo. Adapun Pemerintah diwakili oleh Robinson Simbolon memberikan penjelasan singkat terhadap perkara dimaksud yakni Terhadap anggapan Pemohon yang menyatakan ketentuan Pasal 55 ayat (2) dan ayat (3) Undang-Undang Perbankan Syariah telah menimbulkan adanya ketidakpastian hukum akibat adanya dualisme lembaga penyelesaian sengleta dalam perbankan syariah. ${ }^{13}$

Keempat, bahwa pada tahap sidang ke-empat ini, pihak pemohon menghadirkan saksi dan ahli untuk memberikan keterangan kepada Majelis Hakim Mahkamah Konstitusi. Sidang yang diselenggarakan pada 20 Desember 2012 ini dihadiri oleh 7 (tujuh) Hakim Mahkamah Konstitusi, Dadang Achmad selaku Pemohon, Kuasa Pemohon, Pendamping Pemohon, dan Ahli dari Pemohon, yakni Ija Suntana dan Dedi Ismatullah, serta Pemerintah. ${ }^{14}$ Pada intinya ahli dari Pemohon memberikan pendapatnya bahwa pencantuman klausula penyelesaian sengketa yang memilih pengadilan di lingkungan Peradilan Umum sebagai forum adalah tidak tepat karena di samping bertentangan dengan konsep kompetensi absolut yang tidak dapat dibagi pada dua lingkungan peradilan yang berbeda, hal ini juga bertentangan dengan kondisi aktual dimana pengadilan di lingkungan Peradilan Umum tidak mempunyai kompetensi di bidang perbankan syariah. Kompetensi di sini tidak hanya dalam artian formal, melainkan secara substantif hakim di lingkungan Peradilan Umum belum memiliki penguasaan terhadap transaksi perbankan syariah yang tidak hanya diliputi oleh asas kebebasan berkontrak, akan tetapi harus comply terhadap ketentuan syariah.

Kelima, pada sidang kelima yang berlangsung pada tanggal 29 Januari 2013 selain dihadiri Pemohon, Kuasa Hukum Pemohon, Pendamping Pemohon, wakil

\footnotetext{
12 Adang Daradjatun (Wakil Komisi III DPR RI) dalam Risalah Sidang Perkara Nomor 93/PUUX/2012 Perihal Pengujian Undang-Undang Nomor 21 Tahun 2008 tentang Perbankan Syariah terhadap Undang-Undang Dasar Negara Republik Indonesia Tahun 1945 tertangal 28 November 2012.

${ }^{13}$ Robinson Simbolon (Wakil Pemerintah) dalam Risalah Sidang Perkara Nomor 93/PUU-X/2012 Perihal Pengujian Undang-Undang Nomor 21 Tahun 2008 tentang Perbankan Syariah terhadap UndangUndang Dasar Negara Republik Indonesia Tahun 1945 tertangal 28 November 2012.

${ }^{14}$ Ija Suntana dan Dedi Ismatullah (ahli Pemohon) dalam Risalah Sidang Perkara Nomor 93/PUUX/2012 Perihal Pengujian Undang-Undang Nomor 21 Tahun 2008 tentang Perbankan Syariah terhadap Undang-Undang Dasar Negara Republik Indonesia Tahun 1945 tertangal 20 Desember 2012.
} 
Pemerintah dan 9 (sembilan) Hakim Mahkamah Konstitusi, sidang kali ini juga dihadiri ahli yang diundang Mahkamah Konstitusi, yakni Muhammad Syafi'i Antonio. Ahli Perbankan Syariah ini memberikan keterangan dengan menyoroti tentang Pasal 55 Undang-Undang Nomor 21 Tahun 2008 dikaitkan dengan Pasal 49 Undang-Undang Nomor 3 Tahun 2006. ${ }^{15}$

Pasca sidang kelima Mahkamah Konstitusi tidak langsung mengambil putusan atas permohonan pengujian Pasal 55 ayat (2) dan (3) Undang-Undang Nomor 21 Tahun 2008 tentang Perbankan Syariah terhadap UUD 1945. Putusan baru diambil dan dinyatakan dalam persidangan terbuka dan dibuka untuk umum pada hari Kamis, 29 Agustus 2013. Terhadap keterangan yang disampaikan Pemohon melalui kuasa hukumnya, Komisi III DPR RI, Pemerintah, Ahli dari Pemohon, dan Ahli dari Mahkamah Konstitusi sebagaimana tersebut di atas, Majelis Hakim Mahkamah Konstitusi berkesimpulan sebagai berikut: ${ }^{16}$

1. Mahkamah berwenang untuk mengadili perkara a quo;

2. Pemohon memiliki kedudukan hukum (legal standing) untuk mengajukan permohonan a quo;

3. Dalil permohonan Pemohon beralasan menurut hukum untuk sebagian;

Atas dasar tersebut, Majelis Hakim Mahkamah Konstitusi dalam amar putusannya menyatakan:

1. Mengabulkan permohonan Pemohon untuk sebagian:

1.1. Penjelasan Pasal 55 ayat (2) Undang-Undang Nomor 21 Tahun 2008 tentang Perbankan Syariah (Lembaran Negara Republik Indonesia Tahun 2008 Nomor 94, Tambahan Lembaran Negara Republik Indonesia Nomor 4867) bertentangan dengan Undang- Undang Dasar Negara Republik Indonesia Tahun 1945;

1.2. Penjelasan Pasal 55 ayat (2) Undang-Undang Nomor 21 Tahun 2008 tentang Perbankan Syariah (Lembaran Negara Republik Indonesia Tahun

\footnotetext{
${ }^{15}$ Muhammad Syafi'i Antonio (ahli Mahkamah Konstitusi) dalam Risalah Sidang Perkara Nomor 93/PUU-X/2012 Perihal Pengujian Undang-Undang Nomor 21 Tahun 2008 tentang Perbankan Syariah terhadap Undang-Undang Dasar Negara Republik Indonesia Tahun 1945 tertangal 29 Januari 2013.

${ }^{16}$ Kesimpulan pada Putusan Majelis Hakim Mahkamah Konstitusi terhadap perkara a quo, 29 Agustus 2013.
} 
TAHKIM, Jurnal Peradaban dan Hukum Islam. Vol.3 No.1 (Maret, 2020) | ISSN : 2597-7962

2008 Nomor 94, Tambahan Lembaran Negara Republik Indonesia Nomor 4867) tidak mempunyai kekuatan hukum mengikat;

2. Memerintahkan pemuatan putusan ini dalam Berita Negara Republik Indonesia sebagaimana mestinya;

3. Menolak permohonan Pemohon untuk selain dan selebihnya. ${ }^{17}$

Berdasarkan uraian jalannya persidangan dan putusan Majelis Hakim Mahkamah Konstitusi tersebut, analisis hukum yang dapat diberikan adalah sebagai berikut:

Bahwa Pengadilan di lingkungan Peradilan Agama pada tahun 2006 mendapatkan tambahan kewenangan, yakni dengan diundangkannya Undang-Undang Nomor 3 Tahun 2006 tentang Perubahan Atas Undang- Undang Nomor 7 Tahun 1989 tentang Peradilan Agama. Pasca undang-undang dimaksud efektif pengadilan agama tidak hanya berwenang dalam menerima, memeriksa, memutus, mengadili dan menyelesaikan sengketa di bidang perkawinan dan kewarisan, melainkan juga di bidang ekonomi syariah.Dalam bagian penjelasan Pasal 49 huruf i disebutkan bahwa yang dimaksud dengan "ekonomi syariah" adalah perbuatan atau kegiatan usaha yang dilaksanakan menurut prinsip syariah, antara lain meliputi: a. bank syari'ah; b. lembaga keuangan mikro syari'ah; c. asuransi syari'ah; d. reasuransi syari'ah; e. reksa dana sayari'ah; f. obligasi syari' ah dan surat berharga berjangka menengah syari'ah; g. sekuritas syari'ah; h. pembiayaan syari'ah; i. pegadaian syari'ah; j. dana pensiun lembaga keuangan syari'ah; dan k. bisnis syari'ah.

Adanya Putusan Mahkamah Konstitusi ini seharusnya juga dijadikan sebagai momentum bagi Bank Syariah dan Unit Usaha Syariah untuk membenahi standar akad syariah pada produk-produknya agar lebih taat terhadap prinsip syariah dan bukannya menggunakan peluang menyelesaikan sengketa ke pengadilan dalam lingkungan Peradilan Umum untuk memperoleh kemenangan dengan mengingat hakim di pengadilan umum belum cukup memahami mengenai akad-akad syariah.

Akhirnya dengan putusan dimaksud harapannya dapat menghilangkan adanya dualisme lingkungan peradilan dalam penyelesaian sengketa perbankan syariah. Sengketa

${ }^{17}$ Diktum Putusan Majelis Hakim Mahkamah Konstitusi terhadap perkara a quo, 29 Agustus 2013 
TAHKIM, Jurnal Peradaban dan Hukum Islam. Vol.3 No.l (Maret, 2020) | ISSN : 2597-7962

perbankan syariah adalah domein dari pengadilan di lingkungan Peradilan Agama atau lembaga penyelesaian sengketa alternatif sepanjang para pihak memperjanjikannya.

\section{Implikasi Yuridis Produk Putusan Mahkamah Konstitusi dalam Putusan Mahkamah Konstitusi Nomor Nomor 93/PUU-X/2012}

Dualisme kewenangan penyelesaian sengketa perbankan syariah menjadi polemik dalam dunia hukum Indonesia. Alih-alih hal tersebut menjadi problematika hukum, yang menjadi perhatian para pihak. Problematika mengenai dualisme kewenangan ini, semakin nyata dengan lahirnya Undang-undang Republik Indonesia Nomor 21 Tahun 2008 Tentang Perbankan Syariah atau biasa dikenal dengan istilah UUPS. Pasal 55 ayat (1) UUPS menyebutkan bahwa "Penyelesaian sengketa Perbankan Syariah dilakukan oleh pengadilan dalam lingkungan Peradilan Agama”. Sementara pada Ayat (2) berbunyi: "Dalam hal para pihak telah memperjanjikan penyelesaian sengketa selain sebagaimana dimaksud pada ayat (1), penyelesaian sengketa dilakukan sesuai dengan isi Akad”. Penjelasan Pasal 55 Ayat (2) mempertegas, bahwa: Yangdimaksud dengan "penyelesaian sengketa dilakukan sesuai dengan isi Akad" adalah upaya sebagai berikut: a. musyawarah; b. mediasi perbankan; c. melalui Badan Arbitrase Syariah Nasional (Basyarnas) atau lembaga arbitrase lain; dan/atau d. melalui pengadilan dalam lingkungan Peradilan Umum". Hal tersebut tentunya tidak sesuai dengan Pasal 49 Undang-undang Republik Indonesia Nomor 3 Tahun 2006 tentang Peradilan Agama, yang dengan jelas dan tegas menyebutkan bahwa: "Pengadilan agama bertugas dan berwenang memeriksa, memutus, dan menyelesaikan perkara di tingkat pertama antara orang-orang yang beragama Islam di bidang: (i) ekonomi syariah" Penjelasan pasal 49 menegaskan bahwa salah satu kegiatan usaha ekonomi syariah adalah perbankan syariah. Bunyi pasal-pasal tersebut bisa dimaknai bahwa terjadi inkonsistensi norma, yang memberikan opsional choice of forum dalam penyelesaian sengketa perbankan syariah, yaitu antara Pengadilan agama dan Pengadilan Umum. Artinya, terdapat dualisme kewenangan penyelesaian sengketa perbankan syariah, yaitu di Pengadilan Umum dan Pengadilan Agama.

Inkonsistensi norma tersebut menimbulkan ketidakpastian hukum bagi pencari 
keadilan dan bahkan mereduksi daya kompetensi peradilan agama. Inilah sebenarnya yang menjadi problematika hukum dalam konteks ini. Problematika hukum mengenai dualisme penyelesaian sengketa perbankan syariah tersebut sekarang sudah mereda. Alihalih, para pencari keadilan terkait perkara bank syariah, sudah merasa lega karena Mahkamah Konstitusi telah mengabulkan permohonan uji materiil Penjelasan Pasal 55 ayat (2) Undang-undang Republik Indonesia Nomor 21 Tahun 2008 Tentang Perbankan Syariah. Dikabulkannya permohonan melalui Putusan Mahkamah Konstitusi Nomor 93/PUU-X/2012, tertanggal 29 Agustus 2013 berarti sengketa yang menyangkut perbankan syariah menjadi kewenangan absolud Pengadilan Agama. Artinya, tidak ada lagi choice of forum.

Menurut Abdul Gafur Anshori penyelesaian sengketa di bidang perbankan syariah diselesaikan melalui peradilan umum berpotensi menimbulkan konflik antar dua lingkungan peradilan yang ada. ${ }^{18}$ Selanjutnya jika dikaji dari asas hukum lex specialis derogat lex generalis ( hukum yang khusus mengenyampingkan hukum yang umum). Asas ini tidak dapat digunakan dalam masalah ini karena dua undang-undang tadi ( UU No. 3 Tahun 2006 dan UU No. 21 tahun 2008) tidak dapat ditentukan undang-undang yang berlaku umum dan undang-undang yang berlaku khusus. Hal ini berbeda dengan UU No 10 Tahun 1998 yang mengatur tentang Perbankan dan UU No 21 Tahun 2008 yang mengatur tentang Perbankan Syariah, UU No. 10 tahun 1998 dapat dikatakan lex generalis dan UU No 21 tahun 2008 dapat dikatakan sebagai lex spesialis, dengan demikian jika dalam kedua undang-undang tersebut ada pengaturan yang berbeda mengenai suatu hal maka bagi bank syariah harus digunakan UU No 21 Tahun 2008.

Dengan demikian, kulminasi atas adanya ketentuan UU Perbankan Syariah terkait penyelesaian sengketa tersebut adalah adanya Putusan Mahkamah Konstitusi Nomor 93/ PUU-X/2012 perihal Pengujian Undang-Undang Nomor 21 Tahun 2008 tentang Perbankan Syariah terhadap Undang-Undang Dasar Negara Republik Indonesia Tahun 1945 (UUD NRI Tahun 1945). Hal pokok dari Putusan a quo adalah norma Pasal 55 ayat (2) dan (3) UU Perbankan Syariah yang dianggap merugikan nasabah dari suatu bank

18 Abdul Ghofur Anshori, Perbankan Syariah di Indonesia, Cet I (Yogyakarta: Gajah Mada University Press, 2007 ), hlm.110. 
syariah karena penyelesaian sengketa yang dilakukan melalui pengadilan dalam lingkungan Peradilan Umum, padahal pengadilan dalam lingkungan Peradilan Agama adalah pengadilan yang memiliki kompetensi menurut Pasal 49 UU Peradilan Agama. Adanya Pasal 55 UU Perbankan Syariah menyebabkan nasabah dirugikan secara konstitusional karena tidak memberikan kepastian hukum sebagai sebuah hak konstitusional. ${ }^{19}$ Hal ini dikarenakan ada dua peradilan yang berwenang dalam hal ada choice of forum dalam perkara dengan substansi dan objek yang sama. ${ }^{20}$ Dalam pertimbangan, Mahkamah Konstitusi menilai bahwa justru ketentuan Penjelasan Pasal 55 ayat (2) a quo tidak memberi kepastian hukum. ${ }^{21}$

Putusan Mahkamah Konstitusi dalam hal pengujian UU secara yuridis mengikat semua orang (erga omnes). ${ }^{22}$ Artinya dalam konteks ini, maka seluruh nasabah dan industri perbankan syariah terikat untuk melaksanakan Putusan a quo, yang mana mempertegas kompetensi Peradilan Agama di bidang ekonomi syariah dan berimplikasi bahwa dalam kontrak pembiayaan antara nasabah dan bank syariah terkait dengan klausul penyelesaian sengketa forumnya tidak ada pilihan lain selain peradilan agama atau lembaga non-litigasi apabila itu memang diperjanjikan. ${ }^{23}$ Pilihan forum melalui lingkungan Peradilan Umum menjadi bertentangan dengan putusan ini dan karenanya berakibat batal demi hukum.

Implikasi yuridis di sini bermakna sebagai suatu dampak yang akan timbul dari munculnya suatu norma hukum, baik secara normatif maupun empiris. Norma hukum berupa putusan Mahkamah Konstitusi, berbeda dengan putusan Majelis Hakim di

${ }^{19}$ Abdul Gani Abdullah, "Solusi Penyelesaian Sengketa Perbankan Syariah Menurut Pasal 49 UU No. 3 Tahun 2006 tentang Perubahan Atas UU No. 7 Tahun 1989 tentang Peradilan Agama dan Pasal 55 UU No. 21 Tahun 2008 tentang Perbankan Syariah”, MakalahSeminar Nasional Undang-Undang No. 21 Tahun 2008 tentang Perbankan Syariah,Yogyakarta: Kampus Terpadu UII, 7 Februari 2009, h.2.

${ }^{20}$ Putusan Nomor 93/PUU-X/20012 perihal Pengujian Undang-Undang Nomor 21 Tahun 2008 tentang Perbankan Syariah terhadap Undang-Undang Dasar Negara Republik Indonesia Tahun 1945, hlm. 37.

${ }^{21}$ Putusan Nomor 93/PUU-X/20012 perihal Pengujian Undang-Undang Nomor 21 Tahun 2008 tentang Perbankan Syariah terhadap Undang-Undang Dasar Negara Republik Indonesia Tahun 1945, hlm. 38 .

22 Tim Penyusun,Hukum Acara Mahkamah Konstitusi, (Jakarta: Sekretariat Jenderal dan Kepaniteraan MKRI,2010), hlm. 59.

${ }^{23}$ Putusan Mahkamah Konstitusi sebenarnya lebih mempertegas kewenangan absolut lingkungan Peradilan Agama di bidang ekonomi syariah. Tanpa adanya putusan tersebut sebenarnya satu-satunya lingkungan peradilan yang berwenang di bidang ekonomi syariah adalah Peradilan Agama, bukan Peradilan Umum walaupun diperjanjikan. 
lingkungan Mahkamah Agung. Bahwa putusan Majelis Hakim Mahkamah Konstitusi secara hukum tidak hanya mengikat para pihak. Artinya walaupun pemohon atas pengujian Undang-Undang adalah seorang yang dirugikan secara konstitusional, akan tetapi putusannya akan mengikat seluruh warga negara.

Dalam konteks ini, maka putusan dari Majelis Hakim Mahkamah Konstitusi tersebut mengikat pihak-pihak yang melakukan transaksi di bidang perbankan syariah. Artinya secara hukum tidak boleh lagi ada nasabah dan Bank Syariah atau UUS membuat klausul penyelesaian sengketa dengan memilih pengadilan di lingkungan Peradilan Umum dengan berlindung di balik asas kebebasan berkontrak. Terkait dengan forum di pengadilan yang berlaku adalah asas legalitas, yakni bahwa di ranah attributive competency tidak dimungkinkan melakukan pilihan forum dengan menunjuk lingkungan peradilan lain. Pilihan untuk sengketa di bidang perdangangan hanya dimungkinkan terhadap forum non-litigasi.

Secara normatif apabila dalam klausula penyelesaian sengketa masih memuat pilihan forum berupa pengadilan di lingkungan Peradilan Umum, maka klausula dimaksud bersifat batal demi hukum (null and void). Hal ini bertentangan dengan kaidah bahwa ketentuan hukum yang imperatif tidak dapat disimpangi melalui perjanjian, walaupun hal tersebut disepakati oleh kedua belah pihak. Putusan Mahkamah Konstitusi mempertegas adanya atributive competency yang dimiliki pengadilan di lingkungan Peradilan Agama di bidang perbankan syariah. Kesepakatan dalam memilih forum hanya dapat direalisasikan di ranah non-litigasi.

Peluang implementasi Putusan Mahkamah Konstitusi Nomor 93/PUU-X/2012 bagi penyelesaian sengketa bisnis dan keuangan syariah di luar perbankan dapat diwujudkan, antara lain melalui penerapan metode penemuan hukum yang ada agar putusan tersebut dapat berlaku dan memiliki kekuatan hukum bagi lembaga dimaksud. Menurut penulis metode yang bisa digunakan adalah metode argumentasi berupa argumentum a fortiori, yakni metode analogi yang memperluas ruang lingkup peraturan yang ada untuk kemudian diterapkan terhadap peristiwa yang serupa, sejenis atau mirip. Metode penemuan hukum ini ditujukan untuk mencari esensi yang bersifat lebih umum dari sebuah peristiwa hukum. Perbankan syariah merupakan bagian dari ekonomi syariah 
dan oleh karenanya terdapat kesamaan esensi di antara keduanya yakni dilingkupi oleh hukum syariah. Putusan Mahkamah Konstitusi Nomor 93/PUU-X/2012 pada hakikatnya merupakan bagian dari penegakan hukum yang memberikan penegasan kompetensi mengadili bagi lingkungan Peradilan Agama di bidang ekonomi syariah. Oleh karena itu, terhadap sengketa di lembaga bisnis dan keuangan syariah di luar perbankan syariah pun berlaku putusan ini. Artinya dalam klausul akad antara nasabah dengan lembaga bisnis dan keuangan syariah adalah melanggar hukum manakala menetapkan forum Peradilan Umum bagi penyelesaian sengketa yang mungkin terjadi. Hakim Pengadilan Negeri sudah seharusnya tidak menerima sengketa bisnis dan keuangan syariah, walaupun para pihak menyepakatinya.

\section{SIMPULAN}

Berdasarkan hasil pembahasan dapat disimpulkan sebagai berikut:

1. Kronologi Perkara Nomor 93/PUU-X/2012 Tentang Penghapusan Penjelasan Pasal 55 Ayat 2 UU Nomor 21 Tahun 2008 adalah terkait dengan adanya ketentuan Pasal 55 yang dianggap merugikan secara konstitusional, khususnya terkait dengan Pasal 28D Bab 10A tentang Hak Asasi Manusia yang menjamin tentang kepastian hukum bagi warganya. Hal ini terjadi karena ada dua peradilan yang berwenang dalam hal ada choice of forum dalam perkara dengan substansi dan objek yang sama.

2. Dalil-dalil Hukum Penghapusan Penjelasan Pasal 55 ayat 2 UU No. 21 Tahun 2008 dalam Putusan Mahkamah Konstitusi Nomor 93/PUU-X/2012 didasarkan adanya teori pilihan dalam menyelesaikan sengketa perbankan syariah tersebut, telah memunculkan kekacauan hukum (legal disorder). teori hukum menyatakan bahwa ketika seorang non muslim masuk kepada peradilan atau perbankan syariah, dia telah melakukan choice of law (pilihan hukum). Ketika dia telah memilih hukum, maka secara langsung dia siap dan ikut diatur dengan aturan dan asas yang ada di lembaga yang dia pilih Sehingga penyelesaian sengketanya harus disesuaikan dengan syariah.

3. Penyelesaian sengketa Perbankan Syariah secara litigasi menjadi kewenangan absolut Pengadilan dalam lingkungan Peradilan Agama, karena para pihak tidak boleh memperjanjikan lain akibat terikat dengan Undang-Undang yang telah menetapkan adanya kekuasaan (kewenangan) mutlak (absolut) bagi suatu badan 
TAHKIM, Jurnal Peradaban dan Hukum Islam. Vol.3 No.1 (Maret, 2020) | ISSN : 2597-7962

peradilan untuk menyelesaikan sengketa namun secara non litigasi para pihak dibebaskan untuk membuat pilihan forum penyelesaian sengketa (settlement dispute option), termasuk menyelesaikan sengketanya melalui Badan Arbitrase Syariah Nasional yang putusannya bersifat final dan binding. Putusan Mahkamah Konstitusi dalam hal pengujian UU secara yuridis mengikat semua orang (erga omnes). Artinya dalam konteks ini, maka seluruh nasabah dan industri perbankan syariah terikat untuk melaksanakan Putusan a quo, yang mana mempertegas kompetensi Peradilan Agama di bidang ekonomi syariah dan berimplikasi bahwa dalam kontrak pembiayaan antara nasabah dan bank syariah terkait dengan klausul penyelesaian sengketa forumnya tidak ada pilihan lain selain peradilan agama atau lembaga non-litigasi apabila itu memang diperjanjikan. Pilihan forum melalui lingkungan Peradilan Umum menjadi bertentangan dengan putusan Mahkamah Konstitusi Nomor 93/PUU-X/2012 dan karenanya berakibat batal demi hukum.

\section{DAFTAR PUSTAKA}

Anshori, A. G. (2007) Perbankan Syariah di Indonesia, Cet I. Yogyakarta: Gajah Mada University Press.

Abdullah, A. G. (2009). Solusi Penyelesaian Sengketa Perbankan Syariah Menurut Pasal 49 UU No. 3 Tahun 2006 tentang Perubahan Atas UU No. 7 Tahun 1989 tentang Peradilan Agama dan Pasal 55 UU No. 21 Tahun 2008 tentang Perbankan Syariah, MakalahSeminar Nasional Undang-Undang No. 21 Tahun 2008 tentang Perbankan Syariah. Yogyakarta: Kampus Terpadu UII.

Antonio, M. S. (2001) Bank Syariah Dari Teori Ke Praktek. Jakarta: Gema Insani Press. Echlos, John M dan Shadily, Hasan. (1996) Kamus Inggris Indonesia Dan Indonesia Inggris. Jakarta: Gramedia.

J.Melong, L.(1999). Metodologi Penelitian Kualitatif (Bandung : Remaja Rosdakarya), dan Husain Usman dan Purnomo Setiady Akbar. cet. ke-3 (2003). Metodologi Penelitian Sosial. Jakarta: Bumi Aksara.

Departemen Pendidikan dan Kebudayaam. (1990) Kamus Besar Bahasa Indonesia . 
TAHKIM, Jurnal Peradaban dan Hukum Islam. Vol.3 No.1 (Maret, 2020) | ISSN : 2597-7962

Jakarta: Balai Pustaka.

Koentjaraningrat. (1982). Kebudayaan Metaliteit dan Pembangunan. Jakarta:

Gramedia.

Putusan MK RI Nomor Nomor 93/PUU-X/2012

Pengujian UU Nomor 21 Tahun 2008 Perkara Nomor 93/PUU-X/2012

Suadi, A. (2017). Penyelesaian Sengketa Ekonomi Syariah.(Suarabaya,: Kencana)

Soemitro, A. (2019). Hukum Ekonomi Syariah dan Fiqh Muamalah di Lembaga Keuangan dan Bisnis Kontemporer. Jakarta : Prenada Media.

Tim Penyusun. (2010). Hukum Acara Mahkamah Konstitusi. Jakarta: Sekretariat Jenderal dan Kepaniteraan MKRI.

Undang-Undang Dasar 1945 Pasal 28D Ayat (1) 
TAHKIM, Jurnal Peradaban dan Hukum Islam. Vol.3 No.1 (Maret, 2020) | ISSN : 2597-7962 